\title{
Patterns of origin, formation and spatial movement of the center of Saint-Petersburg in the 1703-1730s
}

\author{
Sergey Sementsov ${ }^{1, *}$, and Yuri Pukharenko ${ }^{1}$ \\ ${ }^{1}$ Saint Petersburg State University of Architecture and Civil Engineering, St. Petersburg, Russia
}

\begin{abstract}
On the basis of numerous archival and published materials and data, project ideas and the real history of the formation and development of the historical center of Saint-Petersburg on the Gorodskoy Island (in 17031720), Vasilyevsky Island (in 1721-1730) and on the Admiralteyskaya side (since the 1730s) are considered as stages of gradual crystallization of various spatial concepts of the capital's development. The structure of the city center that changed over time is revealed. The results of the study: a fairly clear correspondence is shown between the stages of development of spatial and structural ideas and the transfer of the capital's center to new territories, depending on changes in the state's prestigious landmarks.
\end{abstract}

\section{Introduction}

The center of any city is the main administrative, functional, and compositional unit of all urban life. And it largely determines the international and regional significance of the city itself. Especially-the center of such a historical city as Saint-Petersburg. Many researchers from different countries are studying the features of the foundation and development of the centers of historical cities. For historical cities of Western Europe, Ancient Russia, Novgorod and Moscow Russia, such researches were also almost mandatory. Detailed research on the centers of historical cities in Western Europe can be found in the works of A.V. Bunin, T. F. Savarenskaya, and Y. V. Kositsky. F. A. Petrov, D. O. Shvidkovsky [13]. Ancient Russian cities founded before Peter I and their centers were studied in the works of G. V. Alferova, N. N. Voronin, M. K. Karger, P. A. Rappoport [4-6]. Russian urban planning in general, from ancient Russian architecture up to 1917, is carefully considered in the works of A.V. Lavrov and in multi-volume collective works edited by N. F. Gulyanitsky, E. I. Kirichenko [7-9].

D. O. Shvidkovsky clearly defined the features of the formation of Saint-Petersburg under Peter I: multiple changes in the strategy of spatial, figurative and functional development in response to multiple often impulsive changes in the royal (since 1721 Imperial) vision of this image [10]. Was it a royal whim? Or did some other reality or fantasy dominate?

Under conditions of changes the city's development strategy many times, and then the capital-of course, the attitude to the creation of the city center was also changed. But with

* Corresponding author: s.sementsov@mail.ru 
all this diversity, the center of Saint-Petersburg had its own patterns, which are not always possible to clearly identify and study. Moreover, the data from archival collections are not always "at hand", and in many publications various myths are recorded ("preserved"), which often did not correspond to real historical facts.

\section{Methods}

The paper implements a complex study of the collections of archival textual materials (focused, for example, in Russian State Historical Archive, Russian State Archive of the Navy, National Library of Russia, Archive of Russian Academy of Sciences, etc.), both published, for example - in summary works on the history of Saint-Petersburg, the Russian fleet [11-13] and unpublished, data of historical cartography, available in many original plans of the city in the time of Peter I and Anna Ioannovna (both design and fixation), for example - the plans of D. Trezzini, J.-B. A. Le Blond, N. Herbel and others [14], as well as the first artistic and graphic images of the created city [15], based on numerous published information in the literature, including - in research and memoir publications, for example in the diaries of Bergholtz, in the works of P.N. Petrov and I. E. Grabar [16-18]. The results of identifying the source data were carefully compared and comparative analysis, which allowed us to draw unconventional conclusions that significantly clarify the wellestablished and accepted in the scientific literature aspects of the development of the city as a whole and the formation of its center.

\section{Results and discussion}

The study of archival sources has revealed several stages of development of urban planning "Saint-Peters-Burg" (the so-called Saint-Petersburg under Peter I): 1703-1711, 1712-1715, 1716-1721, 1722-1724. And after the death of Peter I (in January 1725), our attention will be focused on the period of development of Saint-Petersburg (as the city was already called)-1725-1736. Within each of the stages, major urban planning and architectural construction works were carried out, but each new, subsequent stage began with a steep royal change in the vector of development of the city, including its center. Since 1725, under the Imperial rule of Catherine I, Peter II and Anna Ioannovna, the city has also experienced difficult times that impact on the center.

\subsection{3-1711 s.}

Since 1703, Saint-Peters-Burg was formed on the Gorodskoy island (modern - SaintPetersburg island) as a fortress settlement at the wood-earth fortress of Saint-Peters-Burg (1703-1706, military engineer J.-G. Lambert), then - when converting it into a stone-andbrick fortress and building the crownwork to the north of its (from 1706, military engineer D. Trezzini, Peter I). In the center of this settlement, the Cabin of Peter the Great was "founded" (from May 1703). From the fortress to the east up to the Cabin of Peter the Great, the original irregular curved square appeared with Rostov (trade) rows located along the Neva river bank, and to the east of the Cabin of Peter the Great - the Sloboda of dignitaries (from 1703), some administrative buildings transferred there from Moscow Central government bodies (from 1704), the Ancient Russian Sloboda appeared (from 1703-1704), the port of Plitsovaya Gavan was organized at the mouth of the channel between the fortress and kronverk (from 1705). The settlement itself, built up without urban planning plans, had all the features of a Russian irregular settlement, with curved streets (in 
accordance with the characteristics of the terrain and topography), blocks and plots, with unsettled wooden development "mansions".

All other developed territories are located on Vasilyevsky Island, on the Admiralteyskaya and Vyborgskaya sides, on Retusaari island (Reitskar island, modern Kotlin island) were extra-urban territories.

After the victories of the Russian army at Vyborg (1710) and Poltava (1709), by the initiative of the Tsar, the initial reconstruction of the emerging city and its center was carried out. Starting from 1709-1710 in the center of the city, the citywide square acquired a geometrically clear rectangle and became known as the Trinity Square - since the main Trinity Cathedral was being built in the center of the square (1710-1714), not far from it appeared the building of the Solemn Austeria (at the same time-a drinking yard, club, etc.) and a model for the possibility of building of mud hut (half-timbered) house, Rostov Trade rows were moved to the northern border of the square and Gostiny Dvor was built (from 1710). From the square in the fortress, repaired the pontoon bridge, and constructed a citywide Neva wooden jetty. But around this fairly regular square, picturesque (unsettled) by the planning and development territories continued to form: the sloboda of dignitaries was expanded, a New Russian Sloboda (from 1709) and a Tatar Sloboda (from 1710?), sloboda of the Office of municipal Affairs of translated masons (since 1710). These reclaimed areas have been fenced city palisade (from 1711), and from the North and West to protect the city the extra-urban (non-palisade) sloboda of Belozersky regiment (1710) were created, of the Koltovskij regiment (1710). This reconstruction coincided with the arrival of the Royal family in the city (in 1710) and the first celebration of the New Year for Peter I in the reconstructed city itself (1711), which was already unofficially considered the capital [19].

\section{$3.21712-1720 \mathrm{~s}$.}

Since the end of 1711-1712, when "Saint Petersburg" actually (without an official announcement) became the capital of the Russian State, there have been numerous studies and searches for specific territorial, urban planning, imaginative and functional solutions, which, in our opinion, can clarify the issues that worried Peter I: 1). Where to place the new Russian capital? 2). What should it be? 3). What should be the center of this capital?

Here we can draw attention to a number of unfulfilled (purely design) and/or implemented solutions that were developed from the last months of 1711 - early 1712 up to 1720 and consistently specified the answers to the questions we have formulated.

The first proposal was to create a project of the end of 1711 (?) the capital on Kotlin island. The Tsar's decree of January 16 (27), 1712 has already determined that thousands of nobles, merchants and artisans from all over Russia must urgently move to live on this island. For the creation of the capital here by the efforts of Peter I and D. Trezzini developed a grandiose project of regular planning and development along the entire island (the length of the composition is $9.5 \mathrm{~km}$ !), with wide streets (with navigable channels traced along their axes), with 115 residential blocks (for a total of 7278 residential areas) and 46 blocks intended for squares and the placement of temples, squares, and public buildings. But the project has not yet defined the area of the city center. This grandiose project was not carried out $[20 ; 21 ; 22]$ (figure 1). 


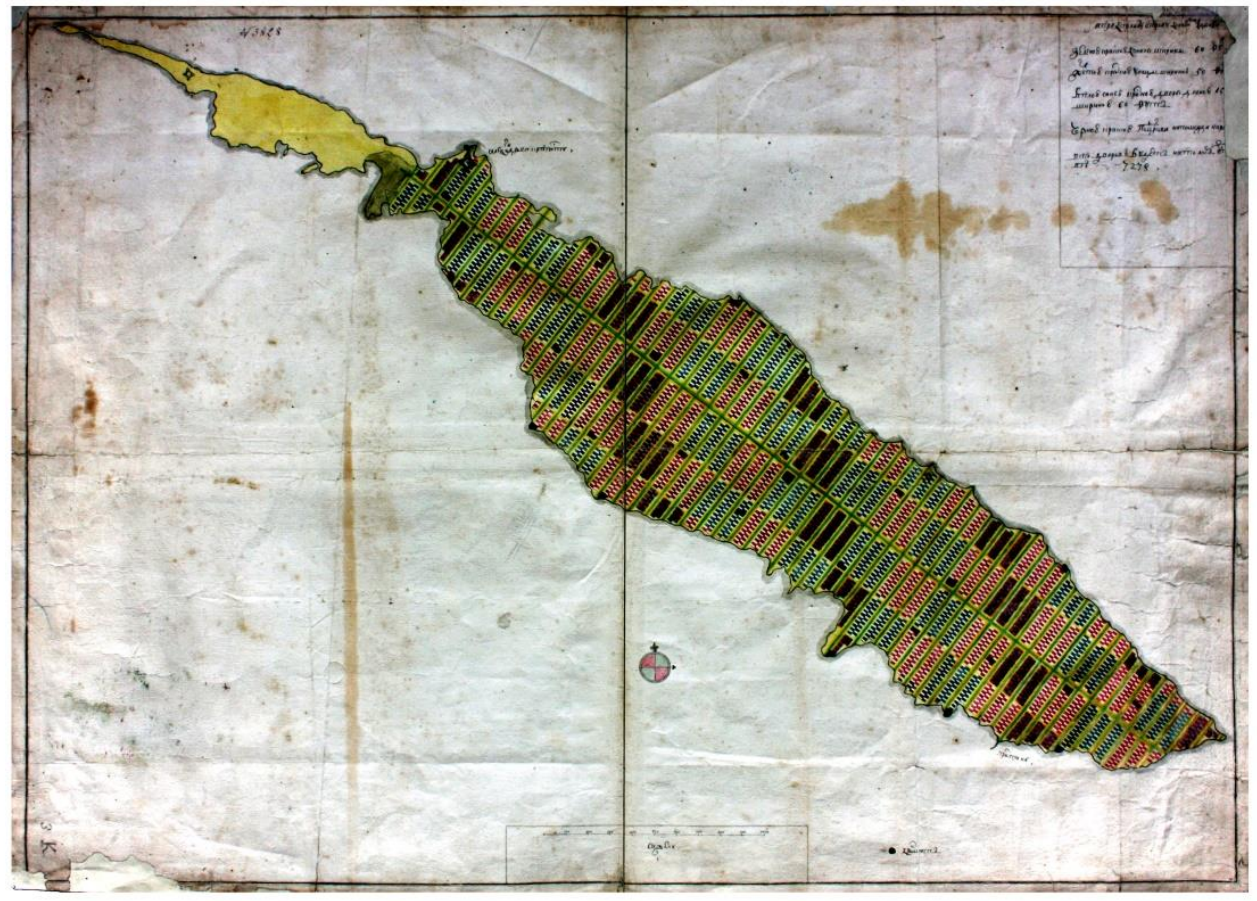

Fig. 1. "The measure to the Kotlin island by channels and yards". 1712 / Research Department of Manuscripts of the Library of the Russian Academy of Sciences. Collection of handwritten maps. The main inventory. No 754 .

The second attempt to create a new regular city-capital was made a few months later, according to a new project, but with the use of urban planning and architectural parameters developed for Kotlin island - it is planned to create the capital in the northern part of the future Moscow side, to the East of the Fontannaya river $(1712$, military engineer D. Trezzini). Here, in a space of $2.5 \times 1.4 \mathrm{~km}$, it is proposed to lay 11 avenues along the bank of the Neva river, cut through them with 6 perpendicular lines to form 56 rectangular city blocks and 1 city-wide rectangular in plan square (to accommodate the center here?). In 1712-1714, the project was tried to implement, only 4 lines were laid along the Neva (now it is Kirochnaya, Furshtatskaya, Chaykovskogo, and Shpalernaya streets). The entire project is presented on the well-known "Plan of N. de Fer" [23].

It is known that in May 1714, Peter I identified a new place for the construction of the city - the bank of the Neva on the Vyborgskaya side, but quickly cooled to the idea. This proposal is recorded in written sources, the project plan is not found, although it is mentioned in the list of works by D. Trezzini [24, 25].

Project for Gorodskoy island reconstruction was provided in 1714, a, with proposals to form two groups of blocks of regular development (in the western and eastern zones of the Gorodskoy island). And in the very center of the Trinity square on its eastern border were built in a single row (along the red line), first 4, then 2 more buildings of Collegia and the Government Senate (from 1714), along the northern border of the square was re-built mud hut Gostiny Dvor (in 1713-1716). The idea of laying two intersecting water channels through the center of the square was also worked out. This project is indicated on the "Palibin Plan" (1716), "Plan of N. de Fer" (1717), "Homann Plan" (1716-1718), "Plan of Bush" (1716-1718) [26].

Since the end of 1715 , numerous works have begun to localize proposals for creating a city on Vasilyevsky island. According to the Supreme decree of October 29 (November 6), 
1715 , it is planned to create an ideal city on the almost undeveloped country still Vasilyevsky island, which was at that time in the possession of A.D. Menshikov. As we know, this project was Supreme approved by Peter I on January 1 (12), 1716, before his trip to Europe (1716, military engineer D. Trezzini). And this project was started to be implemented under the leadership of A.D. Menshikov since 1716. Original design of master plan of D. Trezzini has not yet been found, but on the plans of 1716-1717 ("Plan of I.-B. Homann", "Plan of N. de Fer", "Plan of G.-P. Bush") for Vasilyevsky island already shows a regular planning system, pertly similar to the modern one. The island itself is surrounded by a system of bastions and curtain walls, which should have been a protection against both enemy attacks and the Neva floods. As for the city center, its poorly drawn outlines are defined as two rectangular squares located in the center of the development array, to the North of the future Bolshoy Ave. And the entire Spit of Vasilyevsky island is clearly given over to blocks of elite residential development (and there - no signs of the city center!) [27] (figure 2).

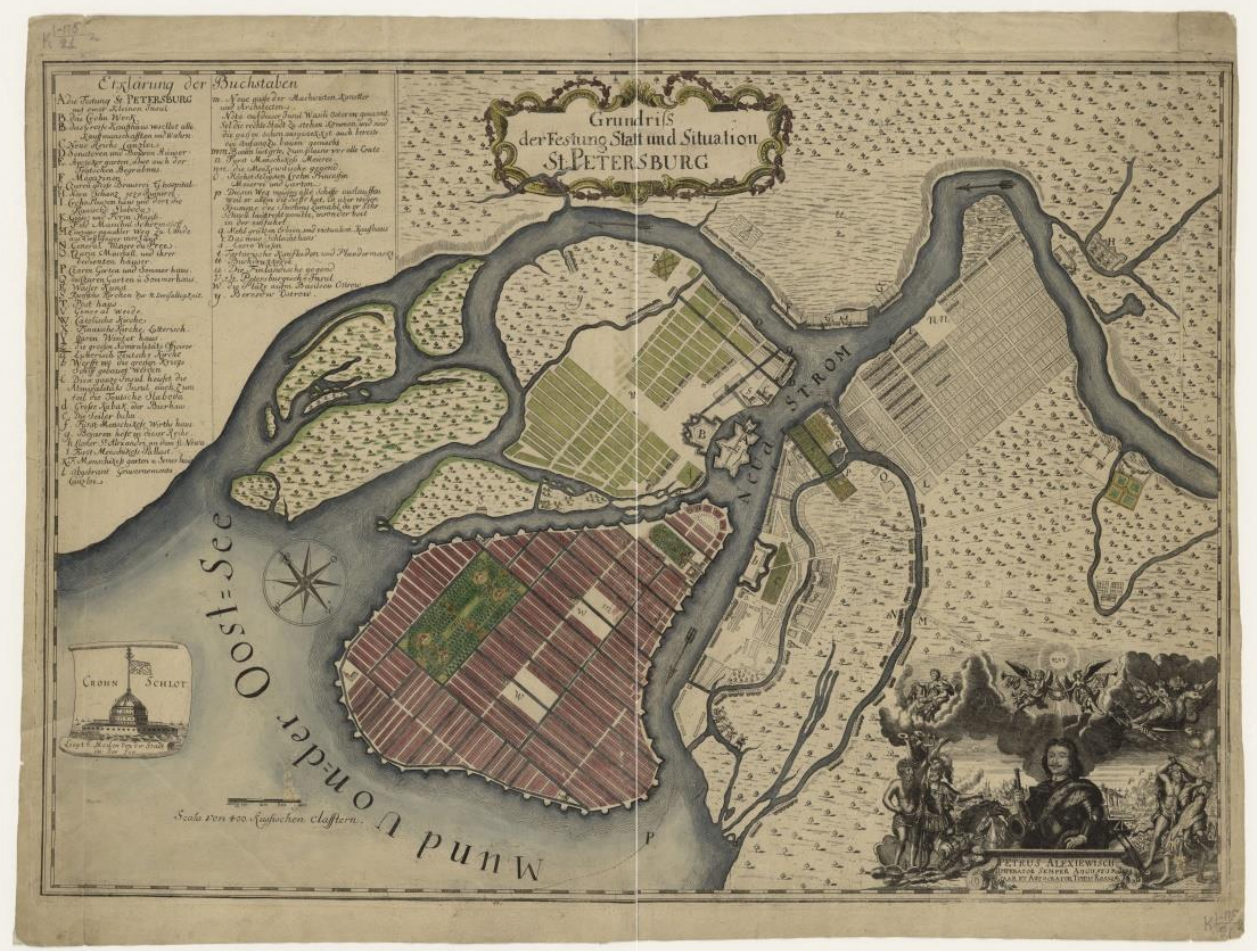

Fig. 2. «GrundrisS der Festung Statt und Situation St:Petersburg» (Translated from German language : "Plan of the fortress of the city and environs of St. Petersburg") ("Plan of G. P. Bush"). 1716-1718. Saint-Petersburg. National Library of Russia K 1-Pb 2/21.

At the very beginning of 1717 , A.D. Menshikov sent by post to Peter I a new design master plan of the entire capital city, known as the "General drawing of Saint -Petersburg", which was prepared "with haste in four days" by J. B.-A. Le Blond and signed by the architect on January 8 (19), 1717. The design master plan of J. B.-A. Le Blond is stored in the Archive of the Academy of Sciences and is widely known for many descriptions and reproductions [28] (figure 3 ). 


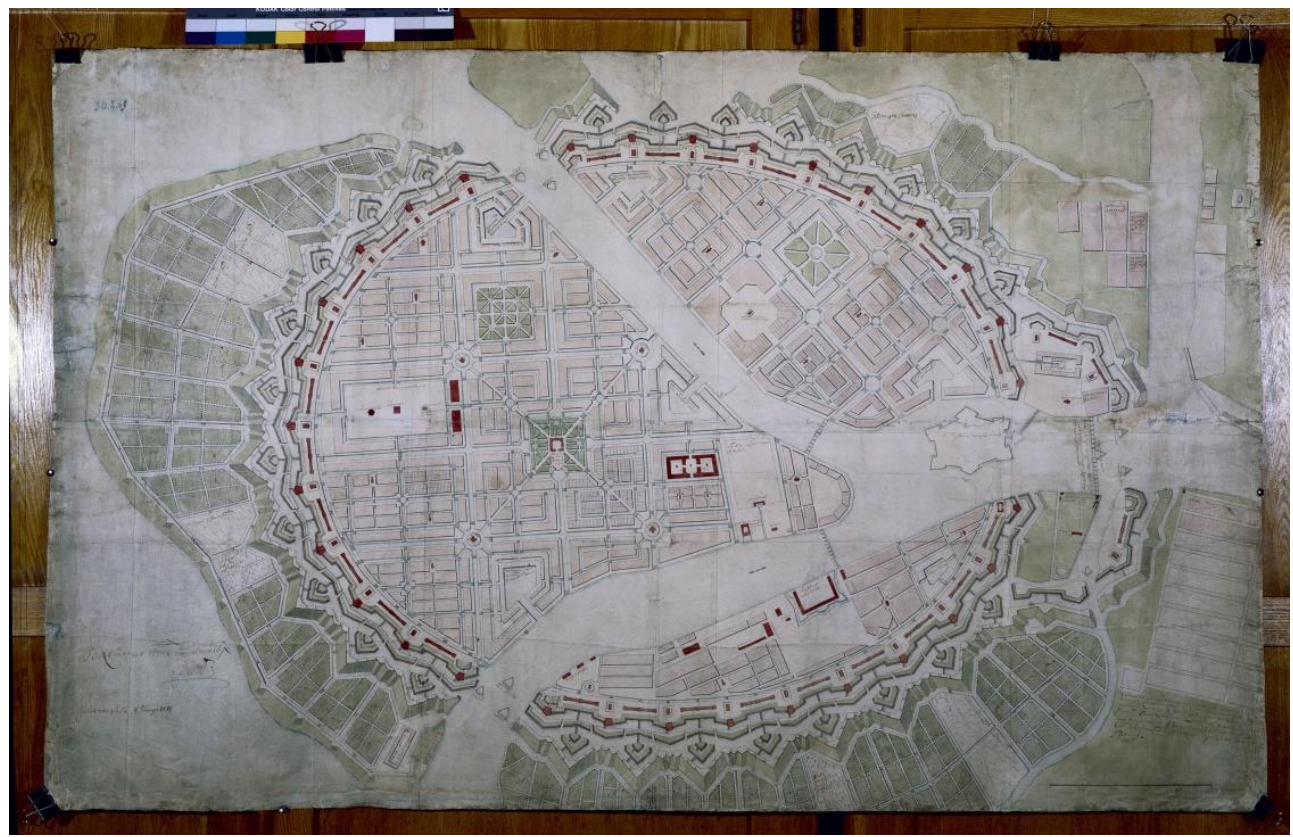

Fig. 3. "General drawing of the Saint-Petersburg" by J.-B. A. Le Blond. 1717. Saint Petersburg branch of the archive of the Russian Academy of Sciences. P. IX. Inventory.1. No 627.

"The Trezzini plan" was persistently implemented by the agencies forces under the personal control of A.D. Menshikov. "The Le Blond Plan" was not implemented. In his project master plan, J.-B. A. Le Blond developed a much more extensive and meaningful functional and compositional program, also focusing mainly on the already implemented planning system and development of Vasilyevsky island. But by making fundamental professional differences in his project. If we look closely, we can say with great confidence that both plans - "Plan of D. Trezzini" and "Plan J.-B. A. Le Blond" have a high degree of compatibility (by tracing latitudinal avenues and Meridian lines, by drawing street exits to the banks of the Neva river). We can assume that J.-B.A. Le Blond, when developing his project, REALLY relied on the planning system approved in the "D. Trezzini project", did not reject it, but refined and masterfully improved it. In the view of the data obtained, it becomes clear why Peter I considered the projects of D. Trezzini and J.-B. A. Le Blond as real and largely compatible planning projects of Vasilyevsky island, competing with each other in the process of implementation [29]. Here we can recall the famous words of the Tsar from a letter dated March 29 (April 9), 1717 to Saint-Petersburg from the Dutch Netherlands: "...About the building on Vasilyevsky island. We must now built houses along the bank against the first drawing that we signed when we were in Petersburg, but we must leave the places where the channels are put into the river against the present Le Blond's drawing, so that by my return, we will choose the best and will do ..."[27, p. 47].

There were many differences between the projects of D. Trezzini and J.-B. A. Le Blond. As for the ideas of creating a new center of a new city, D. Trezzini outlined this topic rather vaguely, but could not formulate the spatial program of the center. And J.-B. A. Le Blond, as a professional architect, (of the level of the French Royal architect) developed this idea much more strongly. He planned to create in the heart of Vasilyevsky island grand multilevel, multi-component ensemble with the Royal Palace of Peter I ("chambers of royal Majesty"), surrounded by parks, channels, neighborhoods of settled residential development, then - the attendant less important ensembles of the areas and major facilities: on Vasilyevsky island - the area for parades ("the place is suspicious"), with a proposal to 
erect a monument to Peter I ("statue of his Majesty walking of metal"), arc column ("the post triumphant"), lighthouse? ("Big tower"); on the Gorodskoy island - another central ensemble - a square with an equestrian statue of Peter I ("Statue of the Royal Majesty on the horse"). And finally, at the corners of the central ensemble on Vasilyevsky island - 4 square squares with 4 temples (according to different Christian denominations, each "cathedral church"). And, again, nothing new has been proposed for Spit of Vasilyevsky island, leaving there to continue the development of residential neighborhoods for the nobility.

But all this remained in the field of urban planning design. The center of the capital city of Saint-Petersburg was still located in its traditional place on the Trinity square of the Gorodskoy island. However, it received an unconventional structure. It already combined: the rectangular regular square itself with the main city Trinity-Peter's Cathedral, with the Solemn Austeria. The area was framed from the South (along the bank of the Neva river) waterfront with berths of the commercial port and marina, from the East by the building of 6 Collegia and the Senate, from the North - Trade rows (Gostiny Dvor), from the West unity of trading pre-kronverk areas, by the Kronwerk itself with the esplanade, the port of Plitsovaya Gavan at the mouth of Kronverk, fortress.

\section{$3.31721-1735 \mathrm{~s}$.}

After the triumphant end of the Great Northern War, during the all - Russian celebrations in 1721, which took place in the center of the capital city -on Trinity square, Peter I was solemnly proclaimed Peter the Great, Father of the Fatherland and Emperor. The Russian State became an Empire, and Saint -Petersburg (as the city was already called) acquired the status of the capital of the Empire. Impulsive and, at the same time, sensitive to the most important nuances of prestige, Peter the Great began to perceive the previously adopted urban planning decisions and the entire ritual of capital life in Saint- Petersburg as outdated, not meeting the increased requirements and Imperial ambitions. It was then, from 17211722 , that the strategy of urban development of the capital was revised anew, and a series of major reconstructive measures were carried out.

The new status of the city required a review of all the general plans of administrative divisions. First of all - the development of a project for the placement of a new city-wide and national center on a new, more prestigious territory - on the Spit of Vasilyevsky island, instead of residential elite neighborhoods being built there. The history of the city shows that since 1720 (on the eve of a military victory) variants were worked out, and since 1722 the creation of the main all-Russian ensemble on the Spit of Vasilyevsky island with the main city-wide square, with new buildings transferred from the Trinity square of Collegia and the Senate (Twelve Collegia were built, the projects reserved space for 3 more buildings), the Cathedral of Saint Andrew the First, Mytny Dvor, the Trading yard, the buildings of the new Commercial port. Thus, in the new conditions, the creation of a new, much more prestigious center was carried out, but almost on the canvas of the old structure of the center, which was polished in the previous period for the conditions of creating a city center on the Gorodskoy island. In the new structure, "only" objects of the Imperial Academy of Sciences have appeared, also as elements of the city-wide center [30, 31].

What about the existing city center on the Gorodskoy island? It began to wither and die quickly. By the early 1730 s, it had become a normal non-central area of local significance.

Difficult times for Saint-Petersburg in 1725-1731 brought many troubles. Including for the city and its center. But, from the very beginning of 1732, when the new Empress Anna Ioannovna returned after her coronation to Saint - Petersburg and settled down with her court in a new place - on the Admiralteyskaya side, in the area of the north-eastern wing of the Admiralty, in the newly built by Rastrelli's father and son the Winter Palace, a new era 
of development of the capital and its urban center began. Since 1732, the center gradually, but inexorably began to move "closer" to the Imperial Winter Palace, on the Admiralteyskaya side -which was still until 1718 the former suburban industrial territory (figure 4).

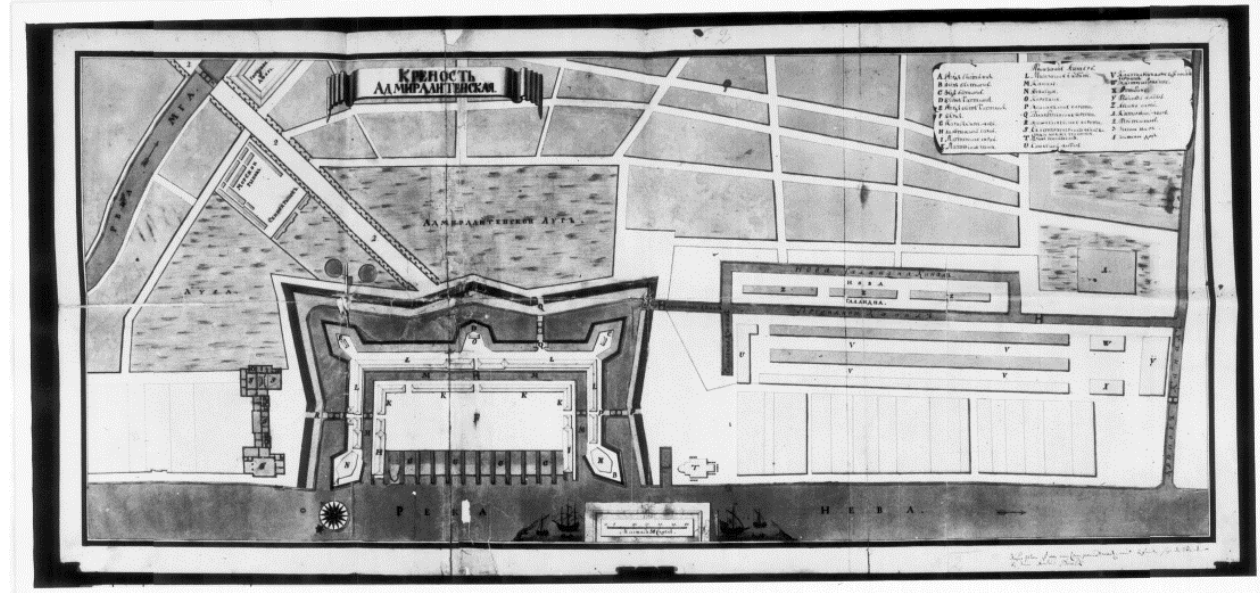

Fig. 4. "Admiralteyskaya Fortress". 1736. Saint-Petersburg. Russian State Archive of the Navy. Fund 3p., Inventory 34. File 2504.

And by 1736, the merchants, for whom continued to build Mytny Dvor and Trading rows on the Spit of Vasilyevsky island, asked for their transfer to the Admiralteyskaya side, to the zone of the Bolshaya road (from 1739 received the name Nevsky prospective, then Nevsky avenue), as on Vasilyevsky island, which inexorably began to turn into the periphery of the city, they were waiting for ruin $[32,33]$.

\subsection{From $1736 \mathrm{~s}$.}

Since 1736-1737, the city-wide center is located on the Admiralteyskaya side until our time. Its multifunctional life on the Gorodskoy island, then - on the Spit of Vasilyevsky island has remained in history. Only since the end of XVIII - beginning of XIX century when a new wave of renovations of the whole capital city Saint-Petersburg and its center by the works of A. Zakharov, A. A. Mauduit, J.-F. Thomas de Tomon, K. I. Rossi came up with a new idea to form a new city center, cementing almost all historically emerging citywide centers into a single huge city center, uniting around the Main space of the Neva river [34].

\section{Conclusions}

The paper highlights the features of the development of the city-wide center of SaintPetersburg ("Saint-Peters-Burg", then - "Saint-Petersburg") in the 1703-1730s as a large multi-element structural object, and an object that under the influence of national ideas, international conflicts, finally - the Royal ambitions and reactions of Peter I, significantly changed its structure, and, in particular, its location. It has passed several stages: on the Gorodskoy island in the area of Trinity square - the center of the fortress settlement, then the center of the city, then - the center of the Russian State; on the Spit of Vasilyevsky Island and then on the Admiralteyskaya side - the city center of the capital of the Russian Empire. 


\section{References}

1. A.V. Bunin, T.F. Savarenskaya, History of urban planning art (Stroizdat, Moscow, 1979)

2. Y.V. Kositsky, Architectural and planning development of cities (Architecture-S, Moscow, 2005)

3. T.F. Savarenskaya, D.O. Shvidkovsky, F.A. Petrov, History of urban planning art. Late feudalism and capitalism (Architecture-S, Moscow, 2004)

4. G.V. Alferova, Russian cities of the XVI-XVII centuries (Stroizdat, Moscow, 1989)

5. N.N. Voronin, P.A. Rappoport, Architecture of Smolensk XII-XIII centuries (Nauka, Leningrad, 1979)

6. M.K. Karger, Novgorod The Great. Architectural monument of Ancient Novgorod (Iskusstvo, Moscow, 1961)

7. V.A. Lavrov, Development of the planning structure of historically formed cities (Stroizdat, Moscow, 1977)

8. N.F. Gulyanitsky, T.F. Savarenskaya, Russian urban planning art, v. 1-5 (Stroizdat, Moscow, 1993-1998)

9. E.I. Kirichenko, The urban planning of Russia in the mid XIX - early XX century, v. 1-3 (Progress-Tradition, Moscow, 2001-2010)

10. D.O. Shvidkovsky, Our heritage 66, 4-29 (2003)

11. F.F. Veselago, Materials for the history of the Russian fleet. Part I (SPb, 1865)

12. T.P. Mazur, The life and work of Admiral Cornelius Kruis (catalog of documents of the Russian State Archive of the Navy) (SPb, 2008)

13. E.A. Andreeva, T.A. Bazarova, G.A. Pobedimova, Y.B. Fomina, Y.N. Bespyatykh, V.N. Ginev, PETERSBURG in the era of Peter I. Catalog of documents. Part 1 (Nauka, SPb, 2003)

14. S.V. Sementsov, Urban development of Saint-Petersburg in the XVIII-early XXI century. Vol. 1. The development of the Neva river territories before the founding of Saint- Petersburg. Development of Saint-Petersburg in the XVIII century (SaintPetersburg State University of Architecture and Civil Engineering, $\mathrm{SPb}, 2011$ )

15. N.V. Kalyazina, G.N. Komelova, Russian art of the Petrine epoch (Artist of the RSFSR, Leningrad, 1990)

16. I. Ammon, Diary of the Chamberlain-Junker Berchholz, conducted by him in Russia in the reign of Peter the Great, from 1721 to 1725 (Moscow, 1857-1862)

17. I.E. Grabar, Petersburg architecture in the XVIII and XIX centuries (Lenizdat, SPb, 1994)

18. P.N. Petrov, History in St. Petersburg from the foundation of the city, till the introduction of the Elective City Administration for the Institutions of the Province. 1703-1782 (Glazunov printing House, SPb, 1884)

19. S.V. Sementsov, Antikvar 1, 7-12 (1993)

20. No 2467. 1712-January 16 (27). Personal order, in points "...about the collection of workers for construction on the Kotlin Island.." Items 13, 14

21. S.P. Luppov, History of the construction of Saint-Petersburg in the first quarter of the XVIII century (Leningrad, Moscow, 1957) 
22. S.V. Sementsov, Project of the city on Kotlin island (1712) as the beginning of the regular architecture of Saint-Petersburg and Russia (Library of the Russian Academy of Sciences, SPb, 2011)

23. I.I. Lisaevich, From the note of D. Trezzini: ... "in 1712, the His Imperial Majecsty ordered to make a drawing of the Moscow side... And all such decrees and orders for the letter were not given to me, but verbally" (Lenizdat, SPb, 1997)

24. Explanation of the historical plans of the Capital city of Saint- Petersburg from 1714 to 1839 (Highest Sovereign of the Emperor decree, SPb, 1843)

25. K.V. Malinovsky, Domenico Trezzini (Kriga, SPb, 2007)

26. M.V. Johannsen, Materials and research on Russian art XVIII - the first half of the X1X century, 73-86 (Moscow, 1984)

27. M.V. Johannsen, Russian art of the XVIII century, 45-55 (1973)

28. S.V. Sementsov, About "General drawing of Saint-Petersburg” J.-B.A. Le Blond 1717 (State Hermitage Museum, SPb, 2000)

29. S.V. Sementsov, J.-B.A. Le Blond and D. Trezzini: town-planning rivalry on Vasilyevsky island in 1716-1718 (State Hermitage Museum, SPb, 1999)

30. M.V. Johannsen, Materials and research on Russian art of the XVIII-first half of the XIX century, 50-72 (Moscow, 1984).

31. S.V. Sementsov, Saint-Petersburg and Peter the Great. The role of the Tsar's personality in the formation of the city-wide center. Determining the structure of the center and the trajectory of its movement on the territory of the capital (State Hermitage Museum, SPb, 2002)

32. Y.N. Bespyatykh, Petersburg of Anna Ioannovna in foreign descriptions: Introduction. Texts. Comments (SPb, 1997)

33. S.V. Sementsov, Bulletin of Saint Petersburg University 15(4), 119-155 (2014)

34. S.V. Sementsov, Bulletin of the Saint Petersburg University 15(1), 173-195 (2013) 